\title{
SM09A and SM09B: Romaine Lettuce Breeding Lines Resistant to Dieback and with Improved Shelf Life
}

\author{
Ivan Simko ${ }^{1}$ and Ryan J. Hayes \\ USDA-ARS, Crop Improvement and Protection Research Unit, 1636 E. Alisal \\ Street, Salinas, CA 93905
}

Krishna V. Subbarao

Department of Plant Pathology, University of California, Davis, c/o U.S. Agricultural Research Station, Salinas, CA 93905

\section{Rebecca Grube Sideman \\ Department of Plant Biology, University of New Hampshire, Durham, NH 03824}

Additional index words. Lactuca sativa, tomato bushy stunt virus, lettuce necrotic stunt virus, salad-cut lettuce, storage, disease resistance, marker-assisted selection

SM09A and SM09B are $\mathrm{F}_{8}$ romaine breeding lines of lettuce (Lactuca sativa L.) resistant to the dieback disease and with good shelf life. SM09B was selected from a cross between 'Darkland' and PI 491224, whereas SM09A was developed from 'Green Towers' $\times$ ('Darkland' $\times$ PI 491224). Resistance to the disease in both breeding lines is derived from PI 491224, a primitive romaine-type lettuce that is highly perishable when processed for salad. In replicated field trials, the two breeding lines showed complete resistance to dieback. Field observations were confirmed through the analysis of molecular markers closely linked to the dieback resistance gene Tvrl. Testing of salad-cut lettuce in modified atmosphere packaging indicated slower decay in the two breeding lines compared with other dieback-resistant romaines.

California and Arizona are the two largest lettuce-producing states, together accounting for over $95 \%$ of the lettuce grown in the United States. Since the early 1990s, dieback disease of lettuce has been observed throughout these two states. Symptoms of the disease include mottling, yellowing, and necrosis of older leaves and the stunting and eventual death of plants (Grube et al., 2005; Obermeier et al., 2001; Wisler and Duffus, 2000). The disease affects romaine and leaf-type lettuce, often leading to crop loss of $60 \%$ or more (Wisler and Duffus, 2000). The disease is caused by two closely related soilborne viruses from the family Tombusviridae-Tomato bushy

Received for publication 19 Jan. 2010. Accepted for publication 1 Mar. 2010.

This project was supported in part by the California Leafy Greens Research Program.

We thank Dov Pechenick and Amy Atallah for molecular marker analyses and Amy Folck for technical assistance. Edward Ryder and Kathleen Haynes critically reviewed the manuscript.

${ }^{1}$ To whom reprint requests should be addressed; e-mail ivan.simko@ars.usda.gov. stunt virus (TBSV) and Lettuce necrotic stunt virus (LNSV) (Obermeier et al., 2001). Previous studies have provided no evidence that either chemical treatment or rotation with nonhost crops can effectively reduce, remove, or destroy the virus in infested soil (Wintermantel and Anchieta, 2003); therefore, genetic resistance remains the only option for disease control.

Lettuce resistance to the disease is coded by a single dominant gene ( $T v r l)$ that is positioned on molecular linkage group 2 (Grube et al., 2005; Simko et al., 2009). Three romaine-type breeding lines with resistance to the disease were previously released by the USDA-ARS in Salinas, CA (Grube and Ryder, 2003). All three breeding lines $(01-778 \mathrm{M}, 01-781 \mathrm{M}$, and 01$789 \mathrm{M}$ ) were derived from a primitive romainetype accession, PI 491224, that has complete resistance to dieback. However, our recent observations show that PI 491224 and all three breeding lines derived from this accession have a very short shelf life after processing into fresh-cut salad. Similarly, feedback from the lettuce industry also indicates that recently developed romaine cultivars with resistance to dieback quickly decay when processed for salad (Hayes and Liu, 2008). Therefore, our breeding program has focused on developing breeding lines with resistance to dieback as well as having acceptable shelf life when processed into salad.

\section{Origin}

SM09A $\left(\mathrm{F}_{8}\right)$ breeding line was selected from a cross between 'Green Towers' $X$ ('Darkland' $\times$ PI 491224), whereas SM09B $\left(\mathrm{F}_{8}\right)$ originated from a cross between 'Darkland' and PI 491224. The dieback resistance in both breeding lines is derived from PI 491224, which is a primitive, romaine-type lettuce accession collected in Greece that is not used for commercial production in the United States. 'Green Towers' is a large and tall romaine cultivar with an erect habit and intense dark green color developed by Harris Moran Seed Co. (Modesto, CA) (COMPOSITdb, 2009). 'Darkland' is a romaine cultivar with a strong bolting tolerance, smooth midribs, and very dark green color (COMPOSITdb, 2009). 'Darkland' was developed by Central Valley Seeds, Inc. (Salinas, CA). The shelf life of 'Green Towers' and 'Darkland' is acceptable to the industry; however, both cultivars are highly susceptible to the dieback disease. SM09A and SM09B were developed by selecting for resistance to dieback disease and horticultural characteristics in experiments conducted in TBSV- and LNSVinfested field sites. Using this approach, single plant selections were made through seven generations of self-pollinations.

\section{Description and Performance}

Assessment of disease resistance, shelf life, and horticultural characteristics. In 2008 and 2009, resistance to dieback was evaluated in SM09A; SM09B; parental materials ('Darkland', 'Green Towers', and PI 491224); previously released dieback-resistant breeding lines 01-778M, 01-781M, 01-789M; recently developed romaine-type cultivars resistant to dieback ('Bandit', 'Defender', and 'Triple Threat'); and green romaine cultivars ('Clemente', 'Heart's Delight', 'Parris Island Cos', and 'Valmaine') susceptible to the disease. The breeding lines were in the $\mathrm{F}_{7}$ and $\mathrm{F}_{8}$ generations, respectively. Both trials were maintained using standard cultural practices for Salinas Valley lettuce production. Resistance to the disease was assessed weekly to discriminate between plants dying from dieback and those from unrelated causes. The proportion of plants that showed typical dieback symptoms (or plants dead owing to dieback) was recorded at harvest maturity. At the same time, two additional trials were performed in a field where dieback disease was not observed. Plants from these experiments were harvested at market maturity, analyzed for horticultural traits, processed for salad, and stored in controlled conditions (Hayes and Liu, 2008). Tissue decay in storage was visually evaluated on a scale of 1 to 5 , in which 1 is no obvious decay, whereas 5 indicates total (or close to total) decay of all tissue after $28 \mathrm{~d}$. Separate trials were set up to evaluate resistance or expression of symptoms to downy mildew (caused by Bremia lactucae), verticillium wilt (caused by Verticillium dahliae race 1), lettuce drop (caused by Sclerotinia minor), big vein (caused by Mirafiori lettuce big-vein virus), and tipburn (physiological disorder) (Davis et al., 1997). Data were analyzed using JMP 6.0.3 (SAS Institute, Cary, NC) and Tukey's honestly significant difference test.

Disease resistance. All plants of SM09A, SM09B, PI 491224, 01-778M, 01-781M, 01789M, 'Bandit', 'Defender', and 'Triple Threat' were free from dieback symptoms during both years. The average disease incidence for 'Darkland' and 'Green Towers' was 0.78 and 0.82 , respectively (Table 1 ). Both breeding lines displayed typical symptoms of downy mildew, lettuce drop, tipburn, verticillium wilt, and big vein. Reaction of 
SM09A and SM09B to downy mildew, lettuce drop, and tipburn was not statistically different from those observed for 'Darkland' and 'Green Towers'. SM09A and SM09B were susceptible to verticillium wilt (race 1), having significantly more disease than the known resistant cultivar Defender (Hayes et al., 2007). Based on a single field experiment, SM09A and SM09B appear to have an intermediate level of resistance to big vein. However, given the extensive genotype $x$ environment interaction for big vein resistance (Ryder and Robinson, 1995), further testing would be needed to confirm this observation. Molecular marker analysis revealed that both breeding lines and parental material carry the Mol allele (Simko, unpublished results) that confers susceptibility to Lettuce Mosaic Virus (LMV) (Nicaise et al., 2003). This confirms earlier greenhouse testing, which revealed that 'Darkland' and 'Green Towers' are susceptible to LMV, whereas PI 491224 is either susceptible or segregates for reaction to the disease (E. Ryder, personal communication).

Shelf life. The average values of tissue decay when testing for shelf life were 2.3 for SM09A and 2.7 for SM09B (Table 2). Overall, the two breeding lines performed significantly $(P \leq 0.05)$ better than the other dieback-resistant accessions (with the exception of 'Defender') and were not significantly worse than dieback-susceptible cultivars.

Morphological description and horticultural characteristics. Both SM09A and SM09B produce closed heads of acceptable size with a core length $\approx 20 \%$ longer and with $10 \%$ more leaves than cvs. Darkland and Green Towers (Table 2). SM09A is light green, whereas SM09B has a medium green color. Limited testing for yield indicates that the proportion of harvestable heads ( 0.92 for
Table 1. Resistance of romaine lettuce to biotic and abiotic factors.

SM09A and 0.70 for SM09B) is similar to other romaine cultivars (with the exception of 'Bandit').

Molecular marker analysis. Both breeding lines and parental material were analyzed with the molecular marker that can be used for marker-assisted selection of resistance to lettuce dieback. Cntg10192 is a molecular marker closely linked to Tvrl, a single dominant gene for resistance to dieback (Simko et al., 2009). Three haplotypes of Cntg 10192 (R1, R2, and R3) are always associated with resistance to the disease, whereas the S1 haplotype is associated with susceptibility (Simko et al., 2009; in press). Molecular marker analysis agrees with phenotypic observations: the presence of the S1 allele in susceptible cvs. Darkland and Green Towers and R2 allele in resistant genotypes SM09A, SM09B, and PI 491224. This confirms that both breeding lines inherited resistance to lettuce dieback from PI 491224.

\section{Availability}

\begin{tabular}{lcccccc}
\hline Accession & TBSV (prop. $)^{\mathrm{z}}$ & DM $(1-5)^{\mathrm{y}}$ & TB (prop. $)^{\mathrm{z}}$ & LD (prop. $)^{\mathrm{z}}$ & VW $\left.^{\text {(prop. }}\right)^{\mathrm{z}}$ & BV (prop. $)^{\mathrm{z}}$ \\
\hline SM09A & $0 \mathrm{c}^{\mathrm{x}}$ & $2.8 \mathrm{ab}$ & $0.53 \mathrm{a}-\mathrm{d}$ & 0.70 & $0.60 \mathrm{a}$ & $0.38 \mathrm{ab}$ \\
SM09B & $0 \mathrm{c}$ & $2.7 \mathrm{ab}$ & $0.23 \mathrm{~cd}$ & 0.72 & - & $0.40 \mathrm{ab}$ \\
$01-778 \mathrm{M}$ & $0 \mathrm{c}$ & $4.3 \mathrm{a}$ & $0.14 \mathrm{~d}$ & - & - & - \\
$01-781 \mathrm{M}$ & $0 \mathrm{c}$ & $3.8 \mathrm{ab}$ & $0.18 \mathrm{~cd}$ & - & - & - \\
$01-789 \mathrm{M}$ & $0 \mathrm{c}$ & $3.9 \mathrm{ab}$ & $0.64 \mathrm{a}-\mathrm{d}$ & - & - & - \\
PI 491224 & $0 \mathrm{c}$ & $3.0 \mathrm{ab}$ & $0.34 \mathrm{~b}-\mathrm{d}$ & 0.73 & - & $0.32 \mathrm{ab}$ \\
Bandit & $0 \mathrm{c}$ & $2.8 \mathrm{ab}$ & $0.74 \mathrm{a}-\mathrm{c}$ & 0.67 & - & $0.24 \mathrm{~b}$ \\
Defender & $0 \mathrm{c}$ & $2.3 \mathrm{~b}$ & $0.89 \mathrm{a}$ & 0.71 & $0.03 \mathrm{~b}$ & $0.15 \mathrm{~b}$ \\
Triple Threat & $0 \mathrm{c}$ & $3.2 \mathrm{ab}$ & $0.67 \mathrm{a}-\mathrm{c}$ & 0.69 & - & $0.18 \mathrm{~b}$ \\
Clemente & $0.74 \mathrm{a}$ & $3.4 \mathrm{ab}$ & $0.62 \mathrm{a}-\mathrm{d}$ & 0.77 & $0.53 \mathrm{a}$ & $0.10 \mathrm{~b}$ \\
Darkland & $0.78 \mathrm{a}$ & $2.7 \mathrm{ab}$ & $0.54 \mathrm{a}-\mathrm{d}$ & 0.79 & $0.73 \mathrm{a}$ & - \\
Green Towers & $0.82 \mathrm{a}$ & $2.4 \mathrm{ab}$ & $0.46 \mathrm{~b}-\mathrm{d}$ & 0.79 & $0.70 \mathrm{a}$ & - \\
Heart's Delight & $0.50 \mathrm{~b}$ & $3.2 \mathrm{ab}$ & $0.57 \mathrm{a}-\mathrm{d}$ & 0.72 & $0.53 \mathrm{a}$ & - \\
Parris Island Cos & $0.78 \mathrm{a}$ & $2.7 \mathrm{ab}$ & $0.74 \mathrm{a}-\mathrm{c}$ & 0.74 & $0.60 \mathrm{a}$ & - \\
Valmaine & $0.47 \mathrm{~b}$ & $2.5 \mathrm{ab}$ & $0.80 \mathrm{ab}$ & 0.71 & $0.70 \mathrm{a}$ & $0.67 \mathrm{a}$ \\
\hline
\end{tabular}

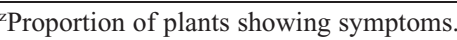

${ }^{y}$ Resistance was visually evaluated on a scale of 1 to 5 , in which 1 is no obvious symptoms, whereas 5 indicates severe infection.

${ }^{x}$ Means within a column followed by different letters are significantly different at $P \leq 0.05$. Dash indicates that the material was not tested.

$\mathrm{TBSV}=$ tomato bushy stunt virus (dieback); $\mathrm{DM}=$ downy mildew; $\mathrm{TB}=$ tipburn; $\mathrm{LD}=$ lettuce drop; $\mathrm{VW}=$ verticillium wilt; $\mathrm{BV}=$ big vein.

Table 2. Horticultural characteristics, yield, and shelf life of romaine lettuce.

\begin{tabular}{|c|c|c|c|c|c|c|c|c|}
\hline \multirow[b]{2}{*}{ Accession } & \multicolumn{6}{|c|}{ Head } & \multirow[b]{2}{*}{$\begin{array}{l}\text { Harvest } \\
\text { (prop.) }^{z}\end{array}$} & \multirow[b]{2}{*}{$\begin{array}{c}\text { S-L } \\
(1-5)^{3}\end{array}$} \\
\hline & $\mathrm{Ht}(\mathrm{cm})$ & $\begin{array}{c}\text { Radius } \\
\text { (cm) }\end{array}$ & Wt (g) & $\begin{array}{c}\text { Leaves } \\
\text { (No.) }\end{array}$ & $\begin{array}{l}\text { Core } \\
(\mathrm{cm})\end{array}$ & $\begin{array}{c}\text { Wt/core } \\
(\mathrm{g} / \mathrm{cm})\end{array}$ & & \\
\hline SM09A & $31.0 \mathrm{ab}^{\mathrm{z}}$ & 32.2 & $1194 \mathrm{a}-\mathrm{c}$ & $56.3 \mathrm{a}-\mathrm{d}$ & $7.7 \mathrm{ab}$ & $163 \mathrm{ab}$ & $0.92 \mathrm{ab}$ & $2.3 \mathrm{~b}$ \\
\hline SM09B & $28.8 \mathrm{ab}$ & 31.6 & $1114 \mathrm{bc}$ & $52.5 \mathrm{a}-\mathrm{e}$ & $7.3 \mathrm{ab}$ & $159 \mathrm{ab}$ & $0.70 \mathrm{bc}$ & $2.7 \mathrm{~b}$ \\
\hline $01-778 \mathrm{M}$ & $29.1 \mathrm{ab}$ & 33.0 & $1161 \mathrm{a}-\mathrm{c}$ & $70.5 \mathrm{a}$ & $6.9 \mathrm{ab}$ & $164 \mathrm{ab}$ & $0.68 \mathrm{bc}$ & $4.5 \mathrm{a}$ \\
\hline $01-781 \mathrm{M}$ & $28.4 \mathrm{ab}$ & 33.3 & $1059 \mathrm{bc}$ & $67.5 \mathrm{ab}$ & $6.9 \mathrm{ab}$ & $149 \mathrm{ab}$ & $0.52 \mathrm{c}$ & $4.6 \mathrm{a}$ \\
\hline 01-789M & $30.5 \mathrm{ab}$ & 32.5 & $1142 \mathrm{a}-\mathrm{c}$ & $60.5 a-c$ & $7.4 \mathrm{ab}$ & $150 \mathrm{ab}$ & $0.86 \mathrm{ab}$ & $4.6 \mathrm{a}$ \\
\hline PI 491224 & $27.2 \mathrm{~b}$ & 33.6 & $1027 \mathrm{c}$ & $59.5 \mathrm{a}-\mathrm{c}$ & $8.3 \mathrm{ab}$ & $138 \mathrm{~b}$ & - & $4.7 \mathrm{a}$ \\
\hline Bandit & $32.8 \mathrm{a}$ & 34.1 & 1333 a & $41.7 \mathrm{de}$ & $9.4 \mathrm{a}$ & $161 \mathrm{ab}$ & $0.97 \mathrm{a}$ & $5.0 \mathrm{a}$ \\
\hline Defender & $29.1 \mathrm{ab}$ & 33.2 & $1073 \mathrm{bc}$ & $39.7 \mathrm{e}$ & $7.4 \mathrm{ab}$ & $168 \mathrm{ab}$ & $0.78 \mathrm{a}-\mathrm{c}$ & $3.3 \mathrm{ab}$ \\
\hline Triple Threat & $30.8 \mathrm{ab}$ & 33.4 & $1206 \mathrm{a}-\mathrm{c}$ & $44.7 \mathrm{c}-\mathrm{e}$ & $8.7 \mathrm{ab}$ & $149 \mathrm{ab}$ & - & $4.9 \mathrm{a}$ \\
\hline Clemente & $29.8 \mathrm{ab}$ & 34.0 & $1258 \mathrm{ab}$ & $49.0 \mathrm{c}-\mathrm{e}$ & $7.3 \mathrm{ab}$ & $180 \mathrm{ab}$ & $0.83 \mathrm{a}-\mathrm{c}$ & $2.3 \mathrm{~b}$ \\
\hline Darkland & $28.7 \mathrm{ab}$ & 32.4 & $1095 \mathrm{bc}$ & $49.3 \mathrm{c}-\mathrm{e}$ & $6.7 \mathrm{ab}$ & $171 \mathrm{ab}$ & $0.81 \mathrm{a}-\mathrm{c}$ & $2.3 \mathrm{~b}$ \\
\hline Green Towers & $28.8 \mathrm{ab}$ & 33.6 & $1053 \mathrm{bc}$ & $50.0 \mathrm{~b}-\mathrm{e}$ & $5.9 \mathrm{~b}$ & $172 \mathrm{ab}$ & $0.79 \mathrm{a}-\mathrm{c}$ & $2.2 \mathrm{~b}$ \\
\hline Heart's Delight & $32.1 \mathrm{ab}$ & 30.6 & $1158 \mathrm{a}-\mathrm{c}$ & $49.7 \mathrm{c}-\mathrm{e}$ & $7.7 \mathrm{ab}$ & $165 \mathrm{ab}$ & $0.87 \mathrm{ab}$ & $2.4 \mathrm{~b}$ \\
\hline Parris Island Cos & $29.0 \mathrm{ab}$ & 32.8 & $1186 \mathrm{a}-\mathrm{c}$ & $46.0 \mathrm{c}-\mathrm{e}$ & $6.4 \mathrm{~b}$ & $181 \mathrm{ab}$ & $0.92 \mathrm{ab}$ & $3.6 \mathrm{ab}$ \\
\hline Valmaine & $28.0 \mathrm{ab}$ & 31.9 & $1059 \mathrm{bc}$ & $48.7 \mathrm{c}-\mathrm{e}$ & $6.7 \mathrm{~b}$ & $186 \mathrm{a}$ & - & $2.6 \mathrm{~b}$ \\
\hline
\end{tabular}

zProportion of plants with harvestable head size.

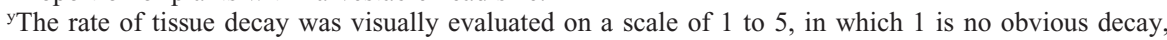
whereas 5 indicates total (or close to total) decay of all tissue.

${ }^{\mathrm{x}}$ Means within a column followed by different letters are significantly different at $P \leq 0.05$. Dash indicates that the material was not tested.

$\mathrm{S}-\mathrm{L}=$ shelf life.
Limited samples of seeds are available for distribution to all interested parties for research purposes, including the development and commercialization of new cultivars. Samples are also deposited in the National Plant Germplasm System under numbers PI 658678 and PI 658679. It is requested that appropriate recognition be made if the breeding lines contribute to research or the development of new germplasm, breeding lines, or cultivars. Written requests should be sent to the first author.

\section{Literature Cited}

COMPOSITdb. 2009. Lettuce cultivar database. 27 Sept. 2009. <http://compositdb.ucdavis.edu/ database/lettcv2/display>.

Davis, R.M., K.V. Subbarao, R.N. Raid, and E.A. Kurtz. 1997. Compendium of lettuce diseases. APS Press, St. Paul, MN

Grube, R.C. and E.J. Ryder. 2003. Romaine lettuce breeding lines with resistance to lettuce dieback caused by Tombusviruses. HortScience 38:627-628.

Grube, R.C., W.M. Wintermantel, P. Hand, R. Aburomia, D.A.C. Pink, and E.J. Ryder. 2005. Genetic analysis and mapping of resistance to lettuce dieback: A soilborne disease caused by Tombusviruses. Theor. Appl. Genet. 110:259-268.

Hayes, R.J. and Y.B. Liu. 2008. Genetic variation for shelf-life of salad-cut lettuce in modifiedatmosphere environments. J. Amer. Soc. Hort. Sci. 133:228-233.

Hayes, R.J., G.E. Vallad, Q.-M. Qin, R.C. Grube, and K.V. Subbarao. 2007. Variation for resistance to verticillium wilt in lettuce (Lactuca sativa L.). Plant Dis. 91:439-445.

Nicaise, V., S. German-Retana, R. Sanjuán, M.P. Dubrana, M. Mazier, B. Maisonneuve, T. Candresse, C. Caranta, and O. LeGall. 2003. The eukaryotic translation initiation factor $4 \mathrm{E}$ controls lettuce susceptibility to the Potyvirus Lettuce mosaic virus. Plant Physiol. 132:12721282.

Obermeier, C., J.L. Sears, H.Y. Liu, K.O. Schlueter, E.J. Ryder, J.E. Duffus, S.T. Koike, and G.C. Wisler. 2001. Characterization of distinct Tombusviruses that cause diseases of 
lettuce and tomato in the western United States. Phytopathology 91:797-806.

Ryder, E.J. and B.J. Robinson. 1995. Big-vein resistance in lettuce: Identifying, selecting, and testing resistant cultivars and breeding lines. J. Amer. Soc. Hort. Sci. 120:741-746.

Simko, I., D.A. Pechenick, L.K. McHale, M.J. Truco, O.E. Ochoa, R.W. Michelmore, and B.E. Scheffler. 2009. Association mapping and marker-assisted selection of the lettuce dieback resistance gene Tvrl. BMC Plant Biol. 9:135.

Simko, I., D.A. Pechenick, L.K. McHale, M.J. Truco, O.E. Ochoa, R.W. Michelmore, and B.E. Scheffler. Development of molecular markers for marker-assisted selection of dieback disease resistance in lettuce (Lactuca sativa L.). Acta Hort. (in press).
Wintermantel, W.M. and A.G. Anchieta. 2003. Tombusvirus infection of lettuce is influenced by soil salinity. Proc. of the 5th symposium of the International Working Group on Plant Viruses with Fungal Vectors; Zurich, Switzerland. p. 131-134.

Wisler, G.C. and J.E. Duffus. 2000. A century of plant virus management in the Salinas Valley of California, 'East of Eden'. Virus Res. 71:161-169. 